\title{
CSR in Universities: A Case Study on Internal Stakeholder Perception of University Social Responsibility
}

\author{
Dr. Zeenat Ismail \\ Professor - Department of Social Sciences \& Liberal Arts \\ Institute of Business Administration - Karachi \\ Neshmia Shujaat \\ Student of Institute of Business Administration, Karachi.
}

\begin{abstract}
Research in CSR has generated a clear understanding on the role of and expectations from sustainable corporations. However, little attention has been directed towards non-corporate institutions such as universities, whose purpose and responsibilities are too ambiguous for any evaluations on them. The aim of this study is to contribute to the sparse literature on University Social Responsibility. This aim is achieved by investigating internal stakeholders' perception of their university's social responsibility initiatives to learn the initiatives that most impact their satisfaction with the institution. The first stakeholder group included 229 undergraduate students and were categorized on basis of their gender, degree program and semester. The second stakeholder group included 75 employees, both administrative and teaching faculty and were categorized on gender, age, tenure and education level. Results showed that students, especially from Business programs and employees were most satisfied when they perceived their university providing quality education, strong industry linkages and equal opportunities to all stakeholders. Specifically, for employees satisfaction levels and USR perceptions grew positively as their university tenure increased. However, after a tenure of 10 years, there was a slight decrease in employee satisfaction and USR perceptions. Both stakeholder groups gave little importance to their university's initiatives on research and innovation, implicating that future research should probe into the cross-cultural relevance of research work at universities.
\end{abstract}

Keywords: University Social Responsibility, CSR, internal stakeholder, satisfaction, students, employees

\section{INTRODUCTION}

The last several decades have seen a burgeoning interest in the social responsibilities of private and public institutions (Burcea \& Marinescu, 2011). Previously, the interest in social responsibility was exclusively directed towards corporate institutions and their contribution to societal well-being. Corporate Social Responsibility [CSR] has been researched extensively and its recent conceptualizations have abandoned its voluntary and philanthropic nature. It is now mandatory for corporate institutions to operate under certain ethical, legal and social guidelines and communicate their policies to relevant stakeholders, transparently (Ojasoo, 2016). Without a commitment to CSR values, corporations in today's diversifying globe are no longer sustainable nor respected. A similar standard of operation is now being anticipated from a host of non-corporate organizations. There is now an increasing expectation from academic institutions to dabble in some form of socially responsible work.

Universities serve as the ultimate example of non-corporate institutions performing social responsibilities. However, lack of research in this area means that the specificities of their 
responsibilities are unclear. Universities are expected to demonstrate an interest in the prosperity of society by incorporating social responsibility values in their teaching, management and research (Latif, 2017). Universities must realize that as higher education has become a competitive market, it is no longer sufficient for them to impart vocational knowledge. To attract talented individuals, they must incorporate social responsibility in their operational strategies (Jimena, 2011). Moreover, the crises in education today is less about declining test scores and more about their failure to produce responsible citizens that possess a breadth of view to engage with social problems (Dima, 2013).

CSR in academic institutions is formally known as University Social Responsibility [USR]. This emerging area of social responsibility seeks to understand the specific form of commitment an academic institution can make to enhance its role in society (Gerholz \& Heinemann, 2015). USR can be understood as a derivative of CSR because it is developed on a similar conceptual model where corporations are expected to manage their impact on people, society, economy and the environment. USR is a concept whereby a university integrates and aligns all its functions and activities with the society's needs. This is done through active engagement with its communities in a transparent and ethical manner with the intent to meet all stakeholders' expectations (Vasquez, 2015). Stakeholder expectations are as important at universities as they are in other corporations.

The application of social responsibility in higher education implies not only the need to identify its stakeholders but also implies the need to understand their perceptions on it. Stakeholder satisfaction with the institution's governance, teaching, research and general quality of service frame their expectations for the institution's future (Vasquez, 2015). To facilitate a deeper understanding of social responsibility in universities, this paper focuses on the various types of initiatives taken by a single university and its impact on stakeholder satisfaction. The ensuing literature review acquaints the reader with important concepts in social responsibility discourses and provides rationale for incorporating CSR models to assess USR perceptions in this study.

\section{Understanding CSR}

\section{LITERATURE REVIEW}

The last several decades have spurred a sense of conscientiousness among global conglomerates to minimize their impact on the environment and to adopt more sustainable development projects. Today companies are faced with the challenge of devising newer strategies for relating to their customers, suppliers, stakeholders and competitors- not simply to fulfill their corporate responsibilities but to also ensure their competitive advantage (Elkington, 1994). The concept of Corporate Social Responsibility [CSR] emerged from the simpler idea of Social Responsibility [SR] where firms took on a business view that ensured the accountability of their impact on society (Hernandez, 2016). Over the span of several decades, numerous definitions and conceptual models have been produced to dismantle and standardize the concept that seemingly encapsulates the conscience of a corporation.

Carol's (1979) three-dimensional model of corporate performance has served as a seminal piece of work for understanding CSR today. He proposed a definition of CSR that encompassed the range of obligations a business has to its society. These obligations fall into four broad categories; economic, legal, ethical and discretionary. A business enterprise's fundamental responsibility lies in being able to provide economic benefit to society since this ensures its own survival. A company's economic responsibilities usually include producing goods in demand, distributing them at reasonable prices and fulfilling the expectations of their shareholders. Businesses are also expected to operate within certain legal regulations, for 
example ensuring the safety of their laborers, protecting the environment and maintain a transparent internal governance structure (Huang, 2006). Ethical responsibilities often embody the business's legal obligations but often go beyond it to guarantee they meet societal values and expectations (Huang, 2006). Discretionary obligations are not responsibilities per se because they solely depend on the business's values and scope to contribute to society. Many businesses today voluntarily participate in promoting societal harmony by taking up philanthropic projects.

Albeit that Carol's (1979) work has provided important groundwork for further research in CSR, it has been frequently disputed by later scholarly work. The increased criticism and evaluation of business structures has led to changes in the conceptualization of CSR over time. Initially, Jones (1980) defined CSR as a firm's obligation to constituent groups in society, including internal and external stakeholders and the voluntary pursuit of activities beyond profit-making. This view was followed by Freeman's (1984) seminal book introducing the stakeholder theory. The theory identified a stakeholder as any individual or group that is affected by or may affect the achievement of a firm's objectives. He produced the stakeholder approach as a philosophy and framework for executives to be able to manage their organizations more effectively (Freeman, 1984). The stakeholder approach to CSR led to a more socially oriented view where businesses were expected to perform these presumably voluntary actions if they were to survive and prosper. Reder (1994) broadened the definition of CSR to include obligations towards not only internal and external stakeholders but also towards the world at large. Woodward-Clyde (1999) described CSR activities as a contract between the business and society, where the society grants a license to the business in return for their socially responsible behavior. The social dimension of CSR eventually incorporated an environmental component which is commonly known in corporate settings as the triple bottom line approach (Foran, 2001; Commission of the European Communities, 2002). Latest definitions of CSR contend that social responsibility initiatives are no longer considered an optional or philanthropic activity. Rather, it is now mandatory that firms and enterprises take into consideration the type of impact they have on the economy, society and the environment (Ojasoo, 2016).

The impact-based model of CSR is a common way to assess performance of organizations across certain dimensions. For example, Carol (1991) illustrates four impacts of a corporation's social responsibilities; philanthropic, ethical, legal and economic. Huang (2006) claims CSR has a legal or moral, philanthropic and economic dimension, given he defines CSR as a sense of volunteerism and social initiative taken by the employees of an organization. On the other hand, Herera (2017) describes three broad impacts of an organization from the average consumer's perspective: social, economic and environmental. In general, most metanalyses reveal that the construct of CSR has four main impact dimensions; economic, ecological, social and stakeholder-related (Buhanita, 2015; Hamidu, Haron \& Amran, 2015; Masoud, 2017).

\section{The Impact of Stakeholders}

Stakeholders have almost always been considered one of the primary concerns of an organization. Hamidu, Haron \& Amran (2015) define stakeholder theory as a relationship of a business organization with a single individual, group(s) or functional bodies that are involved in the process of achieving the organization's objectives. However, the idea first gained mainstream prominence in 1984 after Edward Freeman introduced it in his book titled; "Strategic Management: A Stakeholder Approach." He defined a stakeholder as someone who has a stake or claim in a firm, whose interests eventually shape a firm's purpose and management policies and can affect or are affected by the firm's achievements (Freeman, 1984). Stakeholders can be internal, such as shareholders, employees, customers and suppliers 
or can be external, such as government agencies, competitors, environmentalists, media and special interest groups (Freeman, 1984). Jones (1999) categorized stakeholders as primary and secondary. Primary stakeholders are crucial for the organization's survival because their participation directly impacts its processes. Secondary stakeholders only implicitly affect organizational functions and objectives hence are not crucial for the organization's survival.

Laplume, Sonpar \& Litz (2008) reviewed academic literature on the stakeholder theory from 1984 to 2007. They discovered that newer definitions of the term stakeholder include previously ignored entities such as environmental groups, perhaps because of changes in the understanding of a corporations' responsibilities today. In their critique of the 179 articles they reviewed, they highlighted that many researchers assumed an already well-established stakeholder-firm relationship, especially when they assessed stakeholder-firm relations for CSR performance. Although there is evidence that positive stakeholder relations and their fair treatment leads to firm success in many areas, there is little understanding of the factors that promote these positive relations. Hence, they recommend future research to focus on the attitudinal and behavioral factors that promote a healthy stakeholder-firm relationship.

Hansen (2011) contends that there has been little focus on internal stakeholders such as employees and their capacity to influence organizational outcomes. Their study hypothesized that employees' trust and perception of the firm's CSR activities shapes their relationships with the management and influences their day-to-day performance behavior. They focused on stakeholder trust as a mediating variable to influence employee perception of CSR activities and its eventual impact on performance related behaviors such as turnover intentions and organizational citizenship behavior. Their results showed that employee CSR perceptions mediated by trust were related to decreased turnover intentions and increased organizational citizenship behavior (Hansen, 2011). Several other studies indicate that employees are perhaps the most significant stakeholders in any organization as they are the ones who participate and implement CSR activities. Understanding employee perceptions is important because they directly influence workplace attitudes and behaviors and affect the organization's efficiency and success (Glavas \& Kelley, 2014). In this sense, it is important for employees to find the organization's CSR activities meaningful and relevant to their work. Grounded in the stakeholder theory, Prutina \& Šehić (2016) access a company's 53 store branches across Bosnia and Herzegovina to take employee evaluations of a company's CSR activities. Employee perception of CSR activities included questions regarding the treatment of its various stakeholder groups through surveys and structured interviews. The results of their study showed that a company's genuine commitment to CSR is often indicated by its employees' opinions and further research on employee perceptions can provide a transparent lens on a company's CSR performance.

\section{Employee Perceptions of CSR}

There has been plenty of research conducted on employee perceptions of social responsibility in corporate organizations. Huang (2006) studied 50 enterprises in Taiwan to investigate the variables that influence employees' participation in corporate volunteer work. The results of their study showed that employee perception of CSR has a significant positive correlation with participation in corporate volunteer work. Additionally, their intentions to participate in corporate volunteer work also generated a significant positive effect for organizational commitment. Glavas \& Kelly (2014) discovered that perceptions of CSR are significantly positively correlated with employees' job satisfaction and organizational commitment. Osveh (2015) investigated the effect of employee perceptions of CSR on their work engagement levels in four different organizations in Iran. The study included CSR to both external and internal stakeholders. The results confirmed that employees' perceptions of their organization's CSR 
had a significant positive effect on their engagement where organizational identification played a mediating role.

Contemporary work on this theme reveals that researchers often overlook the impact of background variables. For example, Mensah (2017) conducted a study on 50 rural and community banks in Ghana to investigate the impact of employee engagement in CSR work on their commitment. Although their hypotheses were confirmed, it was discovered that the positive relation between CSR engagement and employee commitment became insignificant when their education level and tenure was taken into consideration. Education and years of working at the bank affected CSR perceptions which resulted in differences in their engagement and commitment levels (Mensah, 2017).

\section{Understanding USR}

The concept of SR has traditionally been attached with large multinational corporations, that is CSR. The intensifying discourse on CSR is now directing questions at academic institutions on the role they play in shaping the environment. The shifting paradigms of modern society imply that universities now play a social role vastly different from before. Therefore, there is an increasing expectation from universities to identify their social responsibility goals, commitments, and objectives and be held accountable for it. Giacalone and Thompson (2006) claim that creating socially responsible citizens should be the primary objective of universities. Gerholz \& Heinemann (2015) claim that a university's two main commitments to society are teaching and research that incorporates social responsibility values. However, teaching and research do not embody the totality of their social responsibility objectives. Rather, CSR ideals must be institutionalized as part of the university's organizational structure. They label a university's civic engagement as its "third mission" apart from the teaching and research.

Dima et al (2013) explain the upsurge in discourse regarding university social responsibility (USR) stating that universities are places that produce forthcoming employees that become the internal stakeholders we refer to in discussions on corporate social responsibility. Universities hold the primary responsibility for disseminating education and research within their communities and with an increasing number of individuals pursuing higher education, the reputation and quality of their programs becomes the distinguishing factor for their success. Additionally, the increased involvement of government and corporations in university affairs, especially in cases of funding, has led to universities following similar patterns of stakeholder relationship management as other corporate institutions (Dima, 2013).

In a similar vein, Vasquez (2015) suggests that universities are not simply education providers but are also shapers of identity and hold major responsibilities to their stakeholders. The identification of university stakeholders is important because it evaluates the quality of their services and shapes their strategies for fulfilling their social responsibility. Universities must pay close attention to the needs and interests of their stakeholders because they are embedded in a network of relations with groups that significantly impact their progress and stability (Latif, 2017).

It is then implied that there are two underlying themes common to the CSR and USR frameworks; firstly, the organization has responsibilities beyond the maximization of wealth and profit and secondly that the organization is not only accountable to its shareholders but also to all varieties of its stakeholders (Herrera et al 2016). CSR in universities is formally referred to as university social responsibility (USR). Vallaeys (2013) defines USR as a policy of ethical quality in the university's activities through the responsible management of four impacts; educational, cognitive, labor and environmental. Vasquez et al (2014) also identify 
four impacts of universities: educational, cognitive, social and organizational. Chen, Nasongkhla \& Donaldson (2015) explored the concept further and describe USR as the university's philosophy or principle to ethically develop and engage with the local and global community with the objective of sustaining six impacts; social, ecological, environmental, technical and economic development. Despite the recognition of university objectives and impacts, there has long existed a gap in literature on reliable measurement of USR. Latif (2017) conducted an exhaustive review to claim that universities have 7 key responsibilities; legal, ethical, philanthropic, operational, internal stakeholders, research/development and community engagement.

\section{Stakeholder Perceptions of USR}

Stakeholder opinions have occupied a central position in discourses on CSR. It is expected that universities must be cognizant of their stakeholders' perceptions too. However, the minimal research on this topic leaves some ambiguity on who can be classified as legitimate stakeholders for universities. Using their four-impact USR model, Vasquez et al (2014) assessed the relationship of student perceptions of USR with their levels of satisfaction and views on their university's quality of service. Their study identified students as the main stakeholders of universities and administered questionnaires on 400 undergraduates from the University of Leon in Spain. Their findings illustrated a strong correlation of USR perception with the variables on satisfaction and quality of service, although these results were indicated by a six-factor model of USR rather than the initial four impact model. The six factors included: external projection, research, education in environmental values, internal management, university-firm relationships, and education in social values (Vasquez et al, 2014).

In another study Ali \& Ali (2016) also identified students as key stakeholders of universities. They gauged student perceptions and awareness of USR in Pakistan. Surveys were conducted across 20 universities and it was found that students had little awareness of the social responsibility initiatives of the university, primarily due to poor communication of these activities. It was also reported that there is a lack of clear vision regarding the universities' social responsibilities which made it increasingly difficult to judge their performance. Some common concerns were that universities did not actively participate in environmental sustainability initiatives and CSR related content was not sufficiently included in course curriculum.

\section{RATIONALE}

Copious amounts of research exist on corporate social responsibility, though there is very little research available on the role of academic institutions in promoting social responsibility (Ali \& Ali, 2016). Universities are as much an integral part of society as corporate firms and are responsible for producing the future workforce for them. This paper addresses a gap in literature and conducts a case study on USR initiatives. Drawing from previous research, it may be safe to assume that students serve as primary, internal stakeholders at universities (Freeman, 1984; Jones 1999, Prutina \& Sehic, 2016). Additionally, keeping the importance of stakeholder relations in mind, the perceptions of employees is researched extensively in corporate environments but not in academic settings. We argue that employees i.e. the administrative and teaching faculty, form a significant part of the stakeholder body for any organization as they form the necessary link between strategies and their implementation. Thus, this study identifies two main stakeholders for universities; students and employees. Previous research has focused on satisfaction levels reported by students, therefore we shall build upon the same theme to add clarity to emerging trends. Hence, both students and employees will be assessed on their satisfaction levels in relation to their perceptions of USR. 


\section{AIMS}

The aim of this study is to investigate internal stakeholder perception of a university's social responsibilities and its relationship with internal stakeholder satisfaction levels. Internal stakeholders include university students and employees. The latter comprise of both; administrative personnel and teaching faculty in the university. Their perception of their university's fulfillment of its social responsibilities are correlated with their satisfaction levels. The broader aim of this study is threefold; to contribute to literature that seems undecided on the future of USR, outline key objectives and goals for university development and to explain how USR activities may be suitably adopted across various cultures.

\section{HYPOTHESES}

1. Ho: Younger students have a favorable perception of USR initiatives than older students do.

2. Ho: Younger students have higher satisfaction with their university than older students do.

3. Ho: Employees with longer tenure have a favorable perception of USR initiatives than those with shorter tenure.

4. Ho: Employees with longer tenure have higher satisfaction with their university than those with shorter tenure.

5. Ho: Older employees are more likely to have a favorable perception of USR initiatives younger employees.

6. Ho: Older employees are more likely to have higher satisfaction with their university than younger employees

7. Ho: Stakeholder satisfaction is significantly, positively correlated with stakeholder USR perception.

\section{Key Terms}

\section{METHODOLOGY}

University Social Responsibility (USR): an ethical approach to develop and engage with the local and global community with the intent to sustain their social, environmental, ecological, technical, and economic development (Chen, Nasongkhla \& Donaldson, 2015, p.165).

Internal Stakeholder: those stakeholders for whom the university's management takes responsibility i.e. in this context, employees and students (Verdeyen, Put \& Buggenhout, 2004, p.327).

Employee Satisfaction: feeling of inner fulfillment and pride felt by the employee with regards to their work, yielding a positive emotion in them that results in better work attitude and performance (Leitmanova \& Fekete, 2016, p. 47).

Student Satisfaction: the extent to which a student's perceived educational experience meets or exceeds their expectations (Vasquez, Aza \& Lanero, 2014, p. 28).

\section{Preliminary measures}

A list of 24 questions were adapted from Vasquez et al's (2014) study on USR. However, for ease of interpretation it was decided that the scale items will be clumped into separate components. The dimensional structure for the scale items was generated through an exploratory factor analysis technique using a principal components analysis and varimax rotation on IBM SPSS 22. The factor analysis initially extracted a five-dimensional structure which accounted for $66.15 \%$ of total variance in the data. Scree plot and a parallel analysis technique suggested the extraction of three factors. The variable's communality extraction 
scores indicated that factor loading criteria be set to .5 and above to avoid cross loadings on multiple components. Items that did not load sufficiently or cross loaded were removed from the questionnaire. The final list of 15 items were then arranged in 3 thematic components that explained $65 \%$ of total variance and showed good internal reliability $(\alpha=.859)$. Component 1 included 7 questions on the university's community service and a well-rounded, holistic education with a high internal reliability $(\alpha=.872)$. Component 2 included 4 questions concerning the provision of equal opportunities for student development $(\alpha=.829)$. Component 3 included questions concerning the university's research and sustainability initiatives with a Cronbach's alpha of .770 for 4 items. The items and their components are summarized in table 1 .

Scale items for student satisfaction were also taken from Vasquez et al's (2014) study. The scale comprised of 6 questions with a high internal reliability as indicated by a Cronbach's alpha of .979. Employee satisfaction was measured via a 20-item scale based on the popularly used Minnesota Satisfaction Survey by Leitmanova \& Fekete (2016). The scale showed good internal reliability as well $(\alpha=.955)$.

Table 1: Component Factor Loadings

\begin{tabular}{|l|c|c|}
\hline \multicolumn{1}{|c|}{ Questionnaire Items } & \multicolumn{2}{|c|}{ Component } \\
\cline { 2 - 3 } & \multicolumn{1}{|c|}{} & 2 \\
\hline
\end{tabular}

\section{Sample and Data Collection Procedure}

Data was collected from students and employees of the Institute of Business Administration (IBA) in Karachi. Two separate questionnaire surveys were administered online and in-person for both stakeholder groups, respectively. Questions on USR remained the same for both surveys, although questions on satisfaction were different for students and employees. Participants were informed that the purpose of the study was to investigate the relationship between IBA's CSR initiatives and their satisfaction with the university. 229 undergraduate students and 53 employees participated in the study. 
Students were categorized on basis of their gender, degree program and semester. The sample included 103 females and 126 males. 76 students were from the Social Sciences program (33.2\%), 75 students were from the BBA program (32.8\%), 38 students were from the Accounting and Finance program (16.6\%), 32 students from the Economics and Maths program (14\%) and 8 students from the Computer Science program (3.5\%). A large majority of student participants were in their final year i.e. $7^{\text {th }}$ (47 students, $\left.20.5 \%\right)$ and $8^{\text {th }}$ (73 students, $31.9 \%)$ semesters. 28 students were in their $6^{\text {th }}$ semester $(12.2 \%), 22$ in their $5^{\text {th }}$ semester (9.6\%), 7 in their $4^{\text {th }}$ semester $(3.1 \%), 2$ in their $3^{\text {rd }}$ semester $(0.9 \%), 9$ in their $2^{\text {nd }}$ semester $(3.9 \%)$ and 41 in their $1^{\text {st }}$ semester $(17.9 \%)$.

Relevant demographic information for employees included their gender, age, tenure and education level. From a total of 75 participants, 60 were male while only 15 were female. 6 participants were 18-25 years old (8\%), 18 were 26-35 years old (24\%), 45 were 36-55 years old (60\%) and 6 were between $56-70$ years (8\%). A large majority of the participants had been working for the university for less than 2 years $(28,37.3 \%) .16$ participants $(21.3 \%)$ had been working between 2-5 years, 18 (24\%) had been working 6-10 years while 13 (17.3\%) had a tenure of 11 years or more. Most employees at the university had a Bachelors degree (64\%). Participant anonymity was guaranteed to all to ensure truthful responses.

\section{RESULTS}

The first set of tests sought to understand the relationship between the two key variables of the study; USR perception and satisfaction. The relationship between them was assessed via a Pearson correlation coefficient test. Preliminary analyses were conducted to ensure the assumptions of normality, homoscedasticity and linearity were not violated. There was a significant, strong, positive correlation between the two variables $[r=.672, n=229, p<0.01]$ for responses recorded by students. The correlation between USR perception and satisfaction was also strong, positive and statistically significant for responses recorded by employees $[\mathrm{r}=.676$, $\mathrm{n}=75, \mathrm{p}<0.01]$.

Since the USR scale had been divided into thematic components via a factor analysis, it was investigated which of the three components had the strongest relation with student, employee and teacher satisfaction, respectively. A standard multiple linear regression analysis was conducted to predict which component of student USR perception impacted their satisfaction with the university. A significant regression equation was found $[F(3,225)=157, p<0.01]$, with an R squared value of .677 indicating a $67 \%$ variance to the dependent variable. The test illustrated that components 1 and 2 significantly predicted student satisfaction while component 3 had the weakest and the only inverse relation of the three components $(\beta=-.206$, $\mathrm{p}<0.01)$. Individually, component 1 moderately predicted student satisfaction $(\beta=.483 . \mathrm{p}<0.01)$ and so did component $2(\beta=.463, \mathrm{p}<0.01)$. To gain further clarity on the item-wise relation between USR and satisfaction, another multiple linear regression analysis was run for component 1 and 2 separately. From component 1 it was learnt that items 19 and 23 most significantly predicted student satisfaction $[F(7,221)=70.6, p<0.05, \beta 19=.396, \beta 23=.433]$. From component 2 , item 21 most significantly predicted student satisfaction $[F(4,224)=73.7$, $\mathrm{p}<0.05, \beta 21=.447]$.

Likewise, a standard multiple linear regression was conducted to predict which component of employee USR perception impacted their job satisfaction. A significant regression equation was found $[\mathrm{R} 2=.479, \mathrm{~F}(3,71)=21.72, \mathrm{p}<0.01]$, the three predictors explaining $47.9 \%$ of total variance. However, the standardized beta coefficients indicated that component 3 did not significantly predict employee satisfaction. Component $1(\beta=.359, \mathrm{p}<0.01)$ and Component 2 $(\beta=.319, \mathrm{p}<0.01)$ significantly and strongly predicted employee satisfaction. Therefore, 
component 3 was removed from further analyses on the employee sample. From component 1 , a significant regression equation demonstrated that item 14 and item 19 most strongly predicted employee satisfaction $[\mathrm{F}(7,67)=13.5, \mathrm{p}<0.05, \beta 14=.351, \beta 19=.375]$. From component 2 , item 15 and item 22 showed the statistically strongest relation with employee satisfaction $[F(4,70)=37.98, p<0.05, \beta 15=.597, \beta 22=.315]$.

The next set of tests assessed the impact of the demographic variables of our participants. A one way between groups analysis of variance was conducted for the five different degree programs to check their mean scores for components 1 and 2. Due to the weak correlations established in the previously conducted multiple regression, component 3 was removed from the analysis. There was a significant difference in the means scores of component1 of USR perception $[\mathrm{F}(4,224)=95.97, \mathrm{p}<0.01]$. From the five programs, students from BS Social Sciences had the least favorable perception of USR $(M=-.82, S D=.57, p<0.01)$ while students from the BBA program had the most favorable perception of USR $(M=1.07, S D=.64, p<0.01)$. Students from Economics \& Maths had the second least favorable perception of component1 $(\mathrm{M}=-.33, \mathrm{SD}=.66, \mathrm{p}<0.01)$, followed by Computer Science program $(\mathrm{M}=-.28, \mathrm{SD}=.22, \mathrm{p}<0.01)$ and then the Accounting and Finance program $(\mathrm{M}=-.12, \mathrm{SD}=.62, \mathrm{p}<0.01)$ as shown in Figure 1.

Figure 1

Descriptives

Zscore(Component1)

\begin{tabular}{|c|c|c|c|c|c|c|c|c|}
\hline & \multirow[b]{2}{*}{$N$} & \multirow[b]{2}{*}{ Mean } & \multirow[b]{2}{*}{ Std. Deviation } & \multirow[b]{2}{*}{ Std. Error } & \multicolumn{2}{|c|}{$\begin{array}{c}95 \% \text { Confidence Interval for } \\
\text { Mean }\end{array}$} & \multirow[b]{2}{*}{ Minimum } & \multirow[b]{2}{*}{ Maximum } \\
\hline & & & & & Lower Bound & Upper Bound & & \\
\hline BBA & 75 & 1.0772481 & .64146774 & .07407031 & .9296598 & 1.2248365 & -1.41402 & 2.06062 \\
\hline SS & 76 & -.8279139 & .57642084 & .06612000 & -.9596317 & -.6961961 & -1.54880 & .99104 \\
\hline $\mathrm{ACF}$ & 38 & -.1285000 & .62429808 & .10127452 & -.3337017 & .0767017 & -1.12594 & .85856 \\
\hline$E \& M$ & 32 & -.3337508 & .66897061 & .11825841 & -.5749404 & -.0925611 & -1.70618 & .85168 \\
\hline $\mathrm{CS}$ & 8 & -.2886412 & .22368157 & .07908338 & -.4756437 & -.1016387 & -.73100 & -.00505 \\
\hline Total & 229 & .0000000 & 1.00000000 & .06608186 & -.1302092 & .1302092 & -1.70618 & 2.06062 \\
\hline
\end{tabular}

ANOVA

\begin{tabular}{|l|r|r|r|r|r|}
\hline & \multicolumn{1}{|c|}{ Zscore(Component1) } \\
\hline Sum of Squares & df & Mean Square & F & Sig. \\
\hline Between Groups & 143.987 & 4 & 35.997 & 95.976 & .000 \\
Within Groups & 84.013 & 224 & .375 & & \\
Total & 228.000 & 228 & & & \\
\hline
\end{tabular}

There was also a significant difference in the scores of component2, $[F(2,224)=33.1, p<0.01]$ with students from BBA perceiving their university's activities most favorably $(\mathrm{M}=.72, \mathrm{SD}=.30$, $\mathrm{p}<0.01)$. Students from the Social Sciences program had the least favorable perception $(\mathrm{M}=-$ $.75, \mathrm{SD}=1.14, \mathrm{p}<0.01)$, followed by the Economics and Maths program $(\mathrm{M}=-.13, \mathrm{SD}=.81$, $\mathrm{p}<0.01)$. The Computer Science $(\mathrm{M}=.29, \mathrm{SD}=.61, \mathrm{p}<0.01)$ and Accounting and Finance $(\mathrm{M}=.13$, $\mathrm{SD}=.61, \mathrm{p}<0.01)$ programs had relatively favorable perceptions of component2 as shown in Figure 2 . 


\section{Figure 2}

Descriptives

Zscore(Component2)

\begin{tabular}{|c|c|c|c|c|c|c|c|c|}
\hline & \multirow[b]{2}{*}{$N$} & \multirow[b]{2}{*}{ Mean } & \multirow[b]{2}{*}{ Std. Deviation } & \multirow[b]{2}{*}{ Std. Error } & \multicolumn{2}{|c|}{$\begin{array}{c}95 \% \text { Confidence Interval for } \\
\text { Mean }\end{array}$} & \multirow[b]{2}{*}{ Minimum } & \multirow[b]{2}{*}{ Maximum } \\
\hline & & & & & Lower Bound & Upper Bound & & \\
\hline BBA & 75 & .7230362 & .30268801 & .03495140 & .6533940 & .7926784 & -.29145 & 1.04340 \\
\hline SS & 76 & -.7568953 & 1.14967915 & .13187724 & -1.0196083 & -.4941824 & -3.29487 & .37597 \\
\hline ACF & 38 & .1388619 & .62024769 & .10061746 & -.0650084 & .3427323 & -1.29259 & .70969 \\
\hline$E \& M$ & 32 & -.1350246 & .81295208 & 14371098 & -.4281251 & .1580758 & -2.29373 & .37597 \\
\hline $\mathrm{CS}$ & 8 & .2925458 & .61144680 & .21617909 & -.2186365 & .8037281 & -.95888 & .70969 \\
\hline Total & 229 & .0000000 & 1.00000000 & .06608186 & -.1302092 & .1302092 & -3.29487 & 1.04340 \\
\hline
\end{tabular}

ANOVA

Zscore(Component2)

\begin{tabular}{|l|r|r|r|r|r|}
\hline & \multicolumn{1}{|c|}{$\begin{array}{c}\text { Sum of } \\
\text { Squares }\end{array}$} & df & Mean Square & F & Sig. \\
\hline Between Groups & 84.749 & 4 & 21.187 & 33.130 & .000 \\
Within Groups & 143.251 & 224 & .640 & & \\
Total & 228.000 & 228 & & & \\
\hline
\end{tabular}

Next, we tested the perception of USR components 1 and 2 in terms of the students' semester. A one way between groups analysis of variance showed that the effect of semester on component 1 was significant at the $p<0.05$ level $[F(7,221)=2.55, p=0.015]$. Post Hoc analyses via a Tukey test showed that there was a significant difference in the mean scores of semester 8 and semester 5 and 6 , with semester 8 students perceiving component1 of USR least positively $(\mathrm{M}=-.30, \mathrm{SD}=.95, \mathrm{p}<0.05)$. There was also a significant difference in means for semester groups for component 2 at the $\mathrm{p}<0.05$ level $[F(7,221)=6.71, p<0.05]$. Students from semester 8 had the least positive score for component 2 of the scale $(M=-.57, S D=1.32, p<0.05]$ while students from semester $2(\mathrm{M}=.52, \mathrm{SD}=.47, \mathrm{p}<0.05)$, semester $5(\mathrm{M}=.49, \mathrm{SD}=.40, \mathrm{p}<0.05)$ and semester $1(\mathrm{M}=.33, \mathrm{SD}=.72, \mathrm{p}<0.05)$ had the most positive mean scores, in that order.

A One way between groups ANOVA test (see Figure 3) showed that degree program had a significant relationship with student satisfaction $[\mathrm{F}(4,224)=76.5, \mathrm{p}<0.05]$. Students from the Social Sciences program showed the lowest satisfaction score $(M=-.97, S D=.86, p<0.05)$ while students from the BBA program showed the highest satisfaction scores $(M=.88, S D=.17$, $\mathrm{p}<0.05)$. Student satisfaction showed a significant relationship with semester in university [F $(7,221)=10.30, \mathrm{p}<0.05]$ with students from 7 th semester $(\mathrm{M}=-.027, \mathrm{SD}=1.02, \mathrm{p}<0.05)$ and 8th semester $(\mathrm{M}=-.63, \mathrm{SD}=1.06, \mathrm{p}<0.05)$ reporting the lowest satisfaction levels. 
Figure 3

Descriptives

Zscore(Total_Satisfaction)

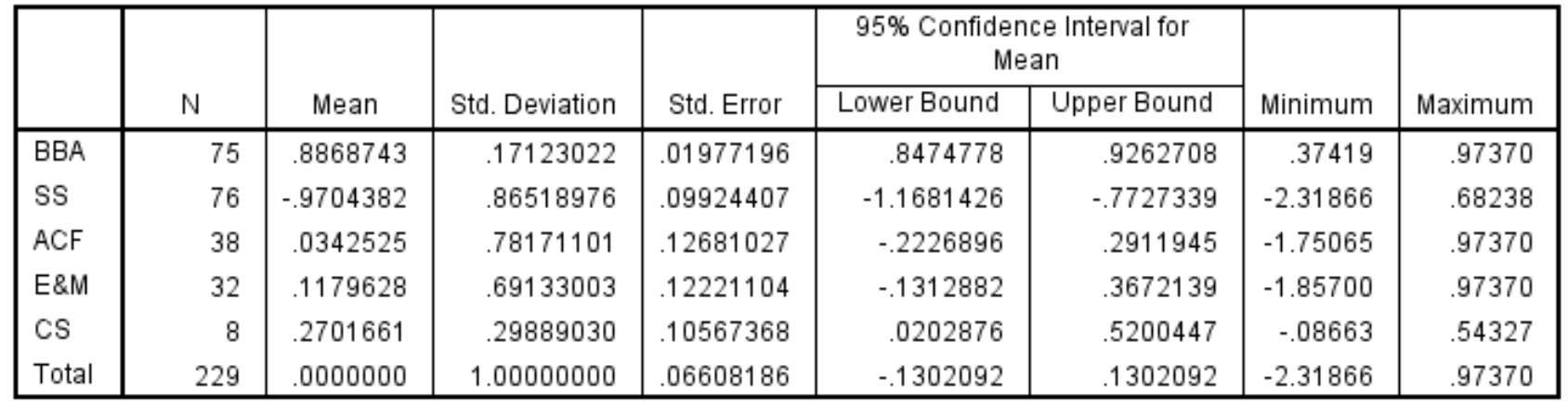

ANOVA

Zscore(Total_Satisfaction)

\begin{tabular}{|l|r|r|r|r|r|}
\hline & \multicolumn{1}{|c|}{$\begin{array}{c}\text { Sum of } \\
\text { Squares }\end{array}$} & df & Mean Square & \multicolumn{1}{c|}{ F } & Sig. \\
\hline Between Groups & 131.638 & 4 & 32.909 & 76.500 & .000 \\
Within Groups & 96.362 & 224 & .430 & & \\
Total & 228.000 & 228 & & & \\
\hline
\end{tabular}

An independent samples $\mathrm{T}$ Test illustrated no significant effect of student gender on USR perception or on student satisfaction levels. The same result was found for the sample on employees. Apart from gender; age and educational level of employees did not impact their USR perception and satisfaction levels either. However, a significant relationship was established with employee tenure through a One-Way ANOVA test $[\mathrm{F}(3,49)=9.58, \mathrm{p}<0.05]$. Employees who had a tenure of less than 2 years displayed the lowest satisfaction scores $(\mathrm{M}=$ $.67, \mathrm{SD}=.76, \mathrm{p}<0.05)$, while those who worked 6-10 years had the highest satisfaction levels $(\mathrm{M}=1.36, \mathrm{SD}=.02, \mathrm{p}<0.05)$, followed by those with a $2-5$ year tenure $(\mathrm{M}=.91, \mathrm{SD}=.61, \mathrm{p}<0.05)$. With regards to USR perception, component 1 showed a significant relationship with employee tenure $[\mathrm{F}(3,49)=11.04, \mathrm{p}<0.05]$. Post Hoc analyses demonstrated a significant difference in perception by employees with a tenure of less than 2 years in comparison to all other employee tenures. Those working for less than 2 years showed the least favorable perception of USR $(\mathrm{M}=-.57, \mathrm{SD}=.91, \mathrm{p}<0.05)$ while those working 6-10 years had the most favorable USR perception $(\mathrm{M}=1.29, \mathrm{SD}=.08, \mathrm{p}<0.05)$.

\section{DISCUSSION}

The present study investigated the impact of internal stakeholder perception of a university's social responsibilities on its satisfaction levels. Internal stakeholders comprised of students and employees. Employees included both, administrative and teaching faculty. Satisfaction as a variable involved two different constructs; student satisfaction and employee satisfaction. The original USR scale involved 24 items, which were reduced to 15 items after an exploratory factor analysis. The items were then categorized into three uncorrelated components via an orthogonal rotation of varimax. Component 1 of the USR scale included 7 questions concerning the university's community service activities and the quality of education provided. Component 2 included 4 questions under the theme of equal opportunities and career development while component 3 included 5 questions on the theme of research and innovation.

The first statistical test was a Pearson's correlation coefficient that confirmed a strong 
relationship between USR perception and stakeholder satisfaction, thereby validating the purpose of this study. USR perception showed a strong relationship with employee satisfaction, although the small sample size could be considered a key determinant of the strength of this result. After establishing significant relations between the variables, a multiple regression analysis was conducted to account for the independent variable's predictive capacity over the dependent variable. First, each of the three components of USR were compared with student satisfaction. The results showed that only components 1 and 2 predicted student satisfaction. This implies that USR activities focused on community service, quality education, equal opportunities and career development are important for students. Activities related to research and innovation, which comprised of component 3 were of little to no importance for students. To enable further clarity on this trend a multiple regression analysis was administered for components 1 and 2, individually. From component 1, items 19 and 23 showed the strongest, significant correlations. Item 19 stated, "My university adapts the course syllabus to the needs and demands of all economic sectors" while item 23 stated, "My university recognizes student opinions and participation." Similarly, for component 2, a significant regression equation was found for item 21, "my university collaborates with employers to improve vocational training and hiring prospects for students." Overall, student satisfaction was greatly determined by how much their university supported their professional development via its teaching and industry linkages. In this regard, final year students, especially from the Social Sciences program had the least positive USR perception and the lowest satisfaction scores with their university. Linking the two results insinuates that students from the social sciences are not content with either their university's teaching or the provision of placement opportunities or perhaps even both. Another program that somewhat matched the opinion of social sciences program was the economics and maths program. Contrariwise, students from the BBA program had the most favorable perception of USR and reported high satisfaction scores, regardless of their semester.

Interestingly, employee satisfaction also showed significant relations with component 1 and component 2 of USR. A multiple regression analysis demonstrated that items 14 "my university has professional ethics and moral contents in its syllabus" and 19 "my university adapts the course syllabus to the needs and demands of all economic sectors" most strongly predicted employee satisfaction from component 1 . On the other hand, items 15 "my university encourages diversity and equal opportunities for workers" and 22 "my university encourages respect for diversity and equal opportunities among students" had the strongest relations with employee satisfaction in component 2. Therefore, just like its students, employees showed greatest satisfaction when they believed that their university was providing quality, wellrounded education as well as fostering values on diversity and equality. The results also showed that employees did not stress on component 3 i.e. research and innovation activities by the university. This seems ironic since career progress for most teaching faculty depends on their research involvement. Hence, it may be argued that the combining of administrative and teaching faculty participants may have skewed this particular result.

Age, gender and education did not significantly relate to employee perceptions of USR or their satisfaction levels. However, tenure was the only variable that did significantly predict USR and satisfaction. Those participants who had been working at the university for less than 2 years showed the lowest satisfaction and least favorable USR perception. This may be perhaps because they were less aware of their university's social responsibility initiatives or they were not as committed to their workplace. It was noted that satisfaction levels and USR perceptions grew positively as the tenure years increased. However, after a tenure of 10 years, there was a slight decrease in employee satisfaction and USR perceptions. 


\section{STRENGTHS, LIMITATIONS AND DIRECTIONS FOR FUTURE RESEARCH}

The present study demonstrates a strong correlation between a university's social responsibilities and its impact on stakeholder satisfaction. A key strength of this study lies in its detection of a gap in literature surrounding themes on CSR, the education system and organizational practices that affect internal stakeholders. The study helps define a newly emergent concept of USR and promotes the identification of students and employees as equal stakeholders within a university. It urges university authorities to understand the expectations of their stakeholders for improved institutional performance. The results from this study serve as a reflection of current satisfaction levels of the university workforce and student body. It highlights the importance of career development and placement opportunities for student satisfaction. Student and employee satisfaction converged on the themes of quality education and equality of opportunity. This suggests that a university's reputation for excellent teaching and practical education alongside its acceptance and encouragement for diversity may serve as an important decision-making factor for choosing a university. Interestingly, items on research and innovation held significance to neither the students nor the employees. Further research can investigate the impact of university research on stakeholders in various cross-cultural settings to learn if this trend applies elsewhere or remains exclusive to this case study since business schools tend to highlight vocational skills more on their curriculum.

A major limitation of this study was its statistically weak sample size for the employee population. Although the study included a majority of the workforce at the Institute of Business Administration, the small sample did influence significance levels for tests conducted on SPSS. It may also be argued that administrative personnel and teachers should have been constructed as separate categories. However, not enough teachers were available to participate in the study. Therefore, the decision was made to merge both groups but that may have skewed the results in this area. Additionally, as a correlational case study, any claims made cannot be generalized onto a population outside of this university. Further research can be conducted and replicated on various other universities across the country to gain a cultural perspective on the expectations from academic institutions in Pakistan. The current study adapted a scale for university social responsibility from a similar study conducted in a Spanish university, though future researchers are highly encouraged to produce a more valid and reliable measure of the USR concept.

\section{CONCLUSION}

University Social Responsibility is a fairly new concept in academia that views universities as integral pillars of the social structure that need to be regulated and held accountable for their activities. Since universities are increasingly managed similar to corporate organizations, this study utilizes the stakeholder approach to understand student and employee satisfaction in relation to USR perception. The results demonstrate the different aspects of a university's responsibilities that attract its internal stakeholders. Students are most concerned with a university's career development capacity and its ability to serve as a bridge between the academic and professional world. At the same time, many students also expect their universities to mimic contemporary world dynamics by embracing diversity and providing equal opportunities for staff and student development. An inclusive university culture provides exposure and preparation for the challenges that lie ahead for graduates in the corporate sector.

Similarly, employees also feel most satisfied working for their university when they believe students are being provided with quality education and that there is equal opportunity for every group at the university. Further research may help define the dynamics of "quality 
education" as well as replicate this study with certain modifications to ascertain whether these trends hold true for other socio-cultural environments as well.

\section{References}

Buhanita, I. (2015). Dimensions in CSR: an evaluation of current definitions. Jurnalism si Comunicare, 4, 64-71.

Burcea, M., \& Marinescu, P. (2011). Students Perceptions on Corporate Social Responsibility at the Academic Level, Case Study:the Faculty of Administration and Business, University of Bucharest. Amfiteatru Economic,13(29), 207-220.

Carroll, A. B. (1979). A Three-Dimensional Conceptual Model of Corporate Performance. The Academy of Management Review, 4(4), 497. doi:10.2307/257850

Chen, S., Nasongkhla, J., \& Donaldson, J. A. (2015). University Social Responsibility (USR): Identifying an Ethical Foundation within Higher Education Institutions. The Turkish Online Journal of Educational Technology, 14(4), 165-172.

Commission of the European Communities. (2001). Promoting a European Framework for Corporate Social Responsibilities, COM (2001) 366 final, Brussels.

Dahlsrud, A. (2006, November 09). How corporate social responsibility is defined: an analysis of 37 definitions. Retrieved October 08, 2017, from http://onlinelibrary.wiley.com/doi/10.1002/csr.132/full

Dima, A., Vasilache, S., Ghinea, V., \& Agoston, S. (2013). A Model of Academic Social Responsibility Transylvanian Review of Administrative Sciences, 38, 23-43.

Elkington, J. (1994). Towards the Sustainable Corporation: Win-Win-Win Business Strategies for Sustainable Development. California Management Review, 36(2), 90-100. doi:10.2307/41165746

Esmaeelinezhad, O., Singaravelloo, K., \& Boerhannoeddin, A. (2015). Linkage between Perceived Corporate Social Responsibility and Employee Engagement: Mediation Effect of Organizational Identification. International Journal of Human Resource Studies, 5(3), 174. doi:10.5296/ijhrs.v5i3.8376

Foran, T. (2001, April). Corporate Social Responsibility At Nine Multinational Electronics Firms In Thailand: A Preliminary Analysis (Rep.). Retrieved http://www.nautilus.org/wpcontent/uploads/2015/06/ThailandReport1.pdf

Freeman, R. E. (1984). Strategic Management: a Stakeholder Approach. Boston: Pitman.

Giacalone, R. A., \& Thompson, K. R. (2006). Business Ethics and Social Responsibility Education: Shifting the Worldview. Academy of Management Learning \& Education, 5(3), 266-277. doi:10.5465/amle.2006.22697016

Glavas, A., \& Kelley, K. (2014). The Effects of Perceived Corporate Social Responsibility on Employee Attitudes. Business Ethics Quarterly, 24(02), 165-202. doi:10.5840/beq20143206

Hamidu, A. A., Haron, H. M., \& Amran, A. (2015). Corporate Social Responsibility: A Review on Definitions, Core Characteristics and Theoretical Perspectives. Mediterranean Journal of Social Sciences, 83-95. doi:10.5901/mjss.2015.v6n4p83

Hansen, S. D., Dunford, B. B., Boss, A. D., Boss, R. W., \& Angermeier, I. (2011). Corporate Social Responsibility and the Benefits of Employee Trust: A Cross-Disciplinary Perspective. Journal of Business Ethics, 102(1), 29-45.

doi:10.1007/s10551-011-0903-0

Herrera, A., Bigne, E., Aldas-Manzano, J., \& Curras-Perez, R. (2015). A Scale for Measuring Consumer Perceptions of Corporate Social Responsibility Following the Sustainable Development Paradigm. Journal of Business Ethics, 140(2), 243-262. doi:10.1007/s10551-015-2654-9

Hernández, M. I., \& Mainardes, E. W. (2016). University social responsibility: a student base analysis in Brazil. International Review on Public and Nonprofit Marketing, 13(2), 151-169. doi:10.1007/s12208-016-0158-7

Huang, C. (2016). Employees' Perception of Corporate Social Responsibility: Corporate Volunteer and Organizational Commitment. International Business Research, 9(9), 142. doi:10.5539/ibr.v9n9p142

Jimena, J. (2011). Universities: The New CSR Frontier. Retrieved November 24, 2017, from http://www.canadianminingjournal.com/features/universities-the-new-csr-frontier/

Jones, T. M. (1980). Corporate Social Responsibility Revisited, Redefined. California Management Review,22(3), 5967. doi: $10.2307 / 41164877$

Jones, M. T. (1999). The Institutional Determinants of Social Responsibility. Journal of Business Ethics, 20(2), 163179. doi:10.1023/a:1005871021412 
Laplume, A. O., Sonpar, K., \& Litz, R. A. (2008). Stakeholder Theory: Reviewing a Theory That Moves Us. Journal of Management, 34(6), 1152-1189. doi:10.1177/0149206308324322

Latif, K. F. (2017). The Development and Validation of Stakeholder-Based Scale for Measuring University Social Responsibility (USR). Social Indicators Research. doi:10.1007/s11205-017-1794-y

Leitmanova, P. and Fekete, M. (2016) Employee satisfaction survey in the selected types of companies in Slovakia. Comenius Management Review, 10 (1), p.45-63.

Masoud, N. (2017). How to win the battle of ideas in corporate social responsibility: the International Pyramid Model of CSR. International Journal of Corporate Social Responsibility, 2(1). doi:10.1186/s40991-017-0015-y

Ojasoo, M. (2016). CSR reporting, stakeholder engagement and preventing hypocrisy through ethics audit. Journal of Global Entrepreneurship Research, 6(1). doi:10.1186/s40497-016-0056-9

Prutina, Z., \& Šehić, D. (2016). Employees Perception of Corporate Social Responsibility: A Case Study of Award Recipient. Ekon Misao I Praksa, 25(1), 239-260

Reder, A. (1994). In pursuit of principle and profit: business success through social responsibility. New York: G.P. Putnams Sons.

Vallaeys, F. (2013). Defining social responsibility: a matter of philosophical urgency for universities. Retrieved December 23, 2017, from http://www.guninetwork.org/articles/defining-social-responsibility-matterphilosophical-urgency-universities

Vasquez, J., \& Lanero, A. (2014). Students' Experiences of University Social Responsibility and Perceptions of Satisfaction and Quality of Service. Econviews Journal, 25-39. doi:159.95-057.87:378.147

Verdeyen, V., Put, J., \& Buggenhout, B. V. (2004). A social stakeholder model. International Journal of Social Welfare, 13(4), 325-331. doi:10.1111/j.1468-2397.2004.00328.x

Woodward-Clyde. (1999) Key Opportunities and Risks to New Zealand's Export Trade from Green Market Signals, final paper, Sustainable Management Fund Project 6117. New Zealand Trade and Development Board: Auckland 